On Taboos: The Danish Cartoon Crisis 2005-2008

Gregersen, Niels Henrik

Published in:

Dialog

Publication date:

2009

Document version

Publisher's PDF, also known as Version of record

Citation for published version (APA):

Gregersen, N. H. (2009). On Taboos: The Danish Cartoon Crisis 2005-2008. Dialog, 48(1), 79-96. 


\title{
Theology Update
}

\section{On Taboos: The Danish Cartoon Crisis 2005-2008 1}

\author{
By Niels Henrik Gregersen
}

\begin{abstract}
The international crisis following the publication of 12 Muhammad cartoons in the Danish newspaper Jyllands-Posten (September 30, 2005) raises the general question of how to exercise the freedom of expression in relation to religious taboos. After briefly reviewing the Cartoon Crisis from September 2005 to the bombings on the Danish Ambassay in Pakistan in June 2008, the article addresses Lutheran resources for coping with secularisation and desecularisation, in particular as regards the taboos that persist as a part of religious and humanistic values. The thesis is that the Lutheran doctrine of the two kingdoms has given rise to two models of interpretation that have both been historically active. The doctrine of the two regiments has been interpreted both as a 'liberalist' argument for a principled separation of religion and politics, and as a 'social-conservative' (later Social Democratic) argument for the view that the state should take care of its citizens' welfare through education, the legal system and social services. In today's global and multi-religious world, this leads us to ask the question to what extent a welfare society, for the sake of peace and social order, should, or should not, protect religious sensitivities. Should religious communities always be kept out of public life, or can they be recognised as non-governmental organizations in civil society, hence as potential partners for the state?
\end{abstract}

Key Terms: Cartoon Crisis, Denmark, doctrine of two kingdoms, freedom of expression, images, Luther, Muhammad, secularization and desecularization, taboos

\section{Introduction}

During 2005 and 2006 Denmark experienced its greatest crisis in foreign politics since the Nazi occupation of Denmark between 1940 and 1945. This crisis was prompted by the publication of twelve seemingly innocent cartoons of the Islamic prophet Muhammad in a Danish Newspaper.

Put in ideological terms, the controversy was about how to negotiate the freedom of expression in a Western society versus the rights of religious communities to exist without being the particular target of scorn. Hence, even the naming of the crisis turned out to be controversial. Was it a "Muhammad-crisis" (as seen from the secular vantage point), or was a "cartoon-crisis" (as seen from the point of view of many Muslims)? Seen in a sociological perspective, the controversy was about the relation between secular society and strongly desecularizing forces of society, such as some Islamic communities in the West. Political analyses of the controversy have naturally focused on the way in which domestic politics, be it in Denmark

Niels Henrik Gregersen is professor of Systematic Theology at Copenhagen University, Denmark, and Co-Director of Naturalism and Christian Semantics, a newly established Center of Excellence at Copenhagen University. He is Editor in Chief of Dansk Teologisk Tidsskrift and a member of the Dialog Editorial Advisory Board. 
or in Middle East countries, often inadvertently escalate conflicts at the level of international politics. Danish politicians have no doubt acted according to perceived notions of what it means to live under a free constitution, and what it means to live the Danish way. Likewise, Muslim politicians have reacted to the crisis in terms of social imaginations of being a genuine Muslim community under attack from a secular and anti-Muslim society.

\section{Taboos and "Two Kingdoms"}

The question to be pursued in this article is how secular societies can deal with the persistence of religious feelings related to taboos. As I argue, taboos are species-wide, and also exist in secular circles. Children, for example, are sexually taboo; and humanists as well as normally sensitive people react strongly against attempts to make fun out of the pains of fellow human beings. This taboo may explain the absolute disgust in most parts of the world upon hearing the President of Iran, Mahmoud Ahmadinejah announce a contest for Holocaust cartoons in reaction to the Danish Muhammad cartoons.

More specifically, however, I explore ways in which ways the Lutheran doctrine of the two kingdoms can be applied to a multi-religious society. I argue that the 'liberalist' interpretation of Luther's doctrine, demanding a clean separation between religion and politics, is not only historically wrong, but also incapable of coping with religious crises coming up on the interface between the public and the private realms of religious life. I also intend to show that the doctrine of the two kingdoms originally was part of a cultural program for society, which can best be termed a 'social-conservative' program. This program has been a seminal inspiration for the development of the comprehensive welfare state in modern continental Europe. It is argued that the doctrine of the two kingdoms may possess untapped resources for recognizing nonChristian communities not only in the public realm of society, but also at political and legal level.

\section{The Muhammad Cartoon Crisis in Outline}

Let me begin by reminding readers of the sequence of events. On September 30, 2005, the major Danish newspaper Jyllands-Posten publicized 12 cartoons of Muhammad, some generally sympathetic, some more satirical, including one depicting an angry man with a bomb in his turban. ${ }^{2}$ One day earlier, September 29, the newspaper's cultural editor, Flemming Rose, explained why Jyllands-Posten had decided to publish the drawings on the following day: "Modern secular society is rejected by some Muslims. They require a special status when insisting on special treatments in relation to their own religious feelings. This is incompatible with a secular democracy with freedom of expression, where one must be ready to endure scorn, mockery, and ridicule." ${ }^{3}$ The immediate background of this intervention was a heated discussion in Denmark (and elsewhere in Europe) about the role of the growing Islamic extremism in Europe. Also, the leftist Danish newspaper, Politiken, had already on September 17, 2005 issued an article titled, "Deep Fears for Criticizing Islam." The article reported that a Danish writer, Kåre Bluitgen, had difficulties finding anyone willing to illustrate his book on the life of Muhammad. 'One said 'No' while referring to the murder in Amsterdam of the instructor Theo van Gogh, another said 'No' with reference to the episode against a teacher at the Carsten Niebuhr Institute." It also reported that a university teacher from the respected Niebuhr Institute at Copenhagen University, not a believer himself, had been caught up by five men and beaten seriously, because he had been reading aloud passages from the Qur'an in Arabic during his lectures. From the point of view of the editor, Jyllands-Posten's agenda was to exercise the courage of the press to defend the tradition of being free to criticize living religions, Islam as well as other religions, even to the point of mockery and ridicule. 


\section{Freedom of Expression vs. Freedom of Religion}

This was not how the situation was seen from the outside, however. Jyllands-Posten has a readership in the center and right end of the political spectrum, some of whom are highly critical of Muslim groups in Denmark. It was therefore hardly a surpise that many Muslims felt themselves particularly targeted by the newspaper. The reactions turned out to be indeed strong. Soon after the publication of the cartoons, on October 4, 2005, a threat was issued anonymously (eventually revealed to be a 17 year old boy) against the cartoonists; this was immediately reported in prime time news. On October 8, the so-called Islamic Faith Community (a Copenhagen-based congregation of partly radicalized Muslims) issued a press release, calling upon Jyllands-Posten to "withdraw unreservedly the cartoons and give an apology to Muslims for its arrogant and respectless action." The editor in chief responded that he could "not dream of" withdrawing or apologizing. On October 14, a major peaceful demonstration by Muslims took place against the newspaper. At the same time, two of the cartoonists were adviced to go underground by the Secret Service, based on threats of death.

By October 2005 the case had escalated from a national debate to the international political scene. October 12, al-Jazeera reported on the cartoons and refered to the statement of the Islamic Faith Community, and the same day 11 ambassadors to Muslims countries requested a meeting with the Danish Prime Minister, Anders Fogh Rasmussen, in order to discuss "actions to be taken" against JyllandsPosten, including a demand to "proceed legally" against the newspaper "in order to secure religious harmony, better integration and improve the relations of Denmark to the Muslim world.” Fogh Rasmussen, however, refused to meet with the ambassadors citing the freedom of expression in Danish and other free societies. As a matter of principle, politicians cannot and should not interfere with the editorial choices of the free press, argued the Prime Minister from the Liberal Party.
The former leader of the Liberal Party and also a former Minister of Foreign Affairs, Uffe Ellemann-Jensen supported the view of the Prime Minister in principle. On October 26, 2005, however, he strongly criticized Jyllands-Posten for its "immature demonstration of freedom," thereby indirectly critizicing the silence of the Prime Minister. As international critiques continued, on December 20 a group of 22 former Danish ambassadors took the highly unusual step of making full-page advertisements in the major newspapers, advising the officials in Denmark to take steps for a serious dialogue with Muslim representatives. The tense public debate in Denmark "can only be seen as a persecution of the minority constituted by Muslims co-citizens," they wrote, and continued: "Both the freedom of religion and freedom of expression are Constitutional rights, but it has never been compatible with Danish attitudes to use the freedom in order deliberately to hurt a minority." 4

\section{Criticisms Mount, Tempers Flare}

The former ambassadors' advertisement was in response to the global reaction on the cartoons. On December 2, a reward of 10,000 dollars was offered by the Pakistan organization Jamaat-e-Islami on the head of the cartoonists, a reward widely publicized, reportedly also during a demonstration in Denmark against Jyllands-Posten. On December 7, a summit of the Organization of Islamic Countries put the cartoons on their agenda, and the same day the UN High-Commisioner for Human Rights, Louise Aarbour, issued a statement that "regrets any declaration or action that can show a failure of respect for the religion of others." On December 27, the cooperation of Muslim collaboration, ISESCO, warned against a forthcoming boycott of Danish trade, followed up on December 29 by a strong critique of the Danish government for its handling of the affair by the foreign ministers of the Arab Liga. Other UN-oficials as well as EU-officials criticized the handling of the affair by Danish authorities. 
By January 2, 2006, it was revealed that a group of well-known Danish imams, led by Abu Laban from the aforementioned Islamic Faith Community, had been travelling around in the Middle East inciting reactions against Denmark. They had distributed a picture of man with a pig-nose as if it were one of the Mohammed-cartoons (eventually the picture was proved to have been taken from a Pig Festival in Southern France that had nothing to do with Muhammad). On January 8, the imams claimed that there is "no written evidence" that they had actually spread misinformation about Denmark in Egypt. Be this as it may, during January 2006 the boycott against Denmark by a long list of Muslim countries went into effect. During the last days of January and the first of February, Danish (and incidentally Norwegian) flags were burned in demonstrations in Gaza and elsewhere.

In response, the French newspaper France Soir and the important German newspaper Die Welt reissued part of the cartoons on February 1, 2006. The conflict could now be interpreted as a more general conflict between the Muslim countries and the West. Politically orchestrated demonstrations were made both in Syria, leading to the burning of the Norwegian-Danish embassy on February 4 (whereby one demonstrant died); followed by the burning of the Danish consulate in Lebanon on February 5, and attacks on the Teheran embassy on February 6. In Afghanistan 11 people were killed during demonstrations February 8; in Pakistan 5 people were tramped down on a demonstration February 14-15; and 17 were killed in Libya on February 17, when the Italian consulate was set on fire. On February 15, 15 were killed during demonstrations in Nigeria, and 11 Christian churches were burnt down. Since then, Denmark has been in the unusual position of being targeted as a particularly anti-Muslim nation. However, during the remainder of 2006 and 2007 many diplomatic initiatives succeeded to put an end to the crisis. Overall, the situation seemed to have calmed down. While Danish products continued to have problems being sold in some Muslim countries, the Danish brand of courage helped exports in other parts of the world.

\section{Throwing Stones?}

On February 12, 2008, however, a new development occurred. The Danish police arrested three persons for planning the murder of Kurt Westergaard, the cartoonist of the man with a bomb in his turban. As a reaction, 17 major newspapers in Denmark republished the cartoons. This led to new demonstrations, and new boycotts. The minister of foreign affairs, Per Stig Møller (himself a member the Conservative party) now said what the liberal Prime Minister would not say: "It is our right to condemn these drawings. Freedom of expression does not mean throwing stones through the neighbor's window. It is only the fundamentalists in both camps that benefit from that sort of action, and this is the real threat against democracy." Interestingly, it is now seen by Per Stig Møller as the right, if not an obligation, of politicians to condemn editorial choices that disturb public order. Likewise, the so-named fundamentalists were no longer only the radical Muslims but also the self-declared liberal secularists. Such a statement was hardly thinkable before the Cartoon Crisis.

As of this date, however, Denmark and Danes are no longer popular in many Muslim countries. The attack on the Danish embassy in Pakistan on June 2, 2008, which resulted in 14 new casualities, exemplifies the situation, as well as the fact that during the Olympic Games in Beijing, August 2008, Danish citizens were rated to be as much a target of terrorist attacks as the participants from Israel and the US. In the views of many, the white swan of H.C. Andersen has once again turned into an ugly duckling.

\section{What to think of the mess?}

In what follows, I move from sociological considerations of the presence of religion in public life to a broader theological analysis. It seems that the Cartoon Crisis gives rise to a more general question: is the proper place of religion in the private sphere only, while in the public sphere, the 
interests of religious groups can be either neglected or rejected cost-free? Or must a modern complex society recognise the presence of various kinds of religious communities and subcultures, each with their vulnerabilities, which society is bound to protect to a reasonable degree without compromising fundamental freedom rights, including the freedom to criticise the claims to validity and socio-ethical consequences of any religion?

It is the latter position of mutual recognition that I wish to promote-in three steps. First, I shall present general historical arguments showing that religion-like education, for example-cuts across both the private and the public sphere. Since religions are practised in social fellowships, they cannot help but have an effect on society as a whole; they are not merely sets of beliefs (in the head), they are also practised by embodied agents in the world at large. And since they also take public form in linguistic and symbolic expressions, religions are always part of public life. Hence any society will have to respond to the pre-political fact of religion, be it through legislation, through teaching in schools, or through political rhetoric. The question is, how?

Second, I shall examine how Lutheranism has had a twofold effect. Through his doctrine of the two kingdoms, Luther laid the groundwork for the distinction between the religious and the political spheres. Lutheranism is often appealed to by proponents of the liberalist idea of society. "Keep Religion Indoors," wrote Prime Minister Anders Fogh Rasmussen in a long essay in the newspaper Politiken (March 20, 2006), while referring to the teachings of Jesus and the doctrine of the two kingdoms by Luther. ${ }^{5}$ Yet at the same time Lutheranism formed the basis of a comprehensive welfare state, where the king-later the politicianswas expected to take care of the citizens' well-being through the legal, educational, health and social systems. In other words, at one and the same time Lutheranism formed the basis for the liberalist distinction between private and public, and for the modern welfare state. The Scandinavianstyle comprehensive welfare state, where resources are shared among all citizens, was set in motion in Denmark by a Conservative government with a pension reform of 1891, but was first realised by Social Democrat governments in the course of the $20^{\text {th }}$ century, most markedly in the Old People's Pensions Act of 1955 (without support from the right-wing parties).

With this in mind I shall conclude some thoughts on the international crisis for Denmark's reputation and economy provoked by the publication of the Muhammad cartoons in 2005.

\section{Secularisation(s)}

The term 'secularisation' can mean many things. As a purely politico-economic concept it means that the property and numerous tasks of the church are gradually taken over by the state. In this sense the beginning of the Reformation in Denmark in 1536 led to an immediate and thorough-going secularisation of Danish society. The king simply took over large areas of church land (which made up roughly one-third of the country), while the state assumed control of all obligations of the public legal system, the education system and social care (including the functions that previously belonged under canon law: church schools, education, and monastic poor relief).

But more commonly, secularisation is used to refer to the lengthy historical process during which religion gradually weakens its hold on the public life of society. I shall settle here for briefly presenting two theories of secularisation which attempt to explain this development from a macro-sociological perspective.

\section{The Rationalist Theory of Secularisation}

The classical 'secularisation thesis' was formulated by the sociologist Max Weber (1864-1920) and the historian of ideas Karl Löwith (1897-1973). Its premise is that Christianity (especially Protestantism) initiated a process of rationalisation by which it will eventually and reluctantly dig its own grave. The process began with an apologetic 'natural theology' in the seventeenth century, and ended up, in the mid-nineteenth century, with Ludwig 
Feuerbach's and Karl Marx's effective critiques of religion, which aimed to show that all images of God are ultimately human projections based on humanity's insatiable demand for meaning and comfort. According to Weber's thesis of 'Occidental Rationalisation,' the 'value-based rationality' with which Christianity's moral universe encircled life has been replaced by 'goal-oriented' rationality'-as we find it for example in political bureaucracy and ethical utilitarianism. 'The good' is what leads to good consequences without anything beforehand being deemed either good or bad 'in itself.'

In principle it is Weber's secularisation theory that is the inheritance of the young Peter L. Berger ${ }^{6}$ and the work of Jürgen Habermas. ${ }^{7}$ On the basis of the above theory, many sociologists in the 1960s and 1970s prophesied the decline of religion, which was seen as a left-over from pre-modern times, and condemned it to an inevitable death. But the theory has been difficult to maintain. In the first place a number of religions have shown the ability to make their case in a rationally understandable form; and secondly, religious life has returned to the agenda even in highly-developed countries like the USA and South Korea. ${ }^{8}$

Already around 1970 Berger was aware of the simultaneity of secularisation and de-secularisation, while it is only in recent years that Habermas acknowledged that religion not only plays a role as an interpreter of the contingencies of life situations (death, guilt, happiness), but also as a source of ethical visions guiding common life. The reason is not least that religion continues to be a cultural resource that forms part of society's preferences, which are never entirely rational. Why, for example, spend money on establishing hospices, when society gets nothing out of them, and why not use the heat from crematoria ovens for district heating?

Recently Habermas published an essay on "Religion in the Public Sphere," in which he reluctantly acknowledged that "the significance of religion for the political objective is now increasing throughout the world... In a world-historical perspective Max Weber's 'Occidental Rationalism' now appears to be a specific historical exception." "And even though Habermas continues to insist that secular reasons should be given priority in the political system, he now admits that liberal democracy neither can nor should "prevent religious citizens from publicly expressing and justifying their convictions in a religious language." He continues: "The liberal state actually has a self-interest in letting the religious voices sound in the political public sphere and in the political participation of religious organisations... The society cannot know whether the secular society would otherwise be cut off from important resources for the formation of opinion and identity." ${ }^{10}$ Acording to this view, there is neither rational reason nor political prudence in an over-hasty reduction of the multi-voiced complexity. Habermas is now prepared to admit that religious traditions may articulate moral intuitions of general importance for the common good, and that religions may also present "cognitive challenges" worth being taken seriously by the secular public. In short, Habermas calls for the emergence of a new political culture in which mutual learning processes can take place between religious and secular views of reality and society.

Habermas is thus today aware of the difficulties of the rationalisation thesis-as a contemporary diagnosis, as a moral position, and as a potentially one-sided cognitive strategy. Religious people-be they Christian, Muslim or Buddhist-are not necessarily less intelligent than everyone else. On the contrary the various religions may contain a reservoir of life-orienting wisdom that cannot easily be tapped into from anywhere else.

\section{Secularisation as a Consequence of the Centreless Society}

A different general theory of secularisation, which in my view is better equipped to explain why religion is simultaneously retreating from the centre of society and yet returning with renewed vigour, is the so-called theory of differentiation. The late German system theorist Niklas Luhmann has argued that a modern hyper-complex society is a centreless society, where the central control of political and religious life of previous ages is no longer possible. We are moving away from a uniform dogmatic religion towards a religious pluralism, in which 
different religious groups coexist with varying world-pictures. At the same time, sporadic resonances of the language- and life-forms of religion are arising in many and various media, from daily and weekly newspapers to literature and art. According to this thesis religion has the almost Sisyphean task of creating coherence in a world that is split up into various systems: the political, the legal, the educational, the religious, the moral, the scientific, the artistic and so on. ${ }^{11}$

The thesis of the centreless society is that all of society's constituent systems lack the ability to define society's centre. The political system also has proved incapable of controlling the economic system from above, just as both moral opinions and religious commitments have shown themselves to be relatively uncontrollable by the political system. The political agenda is thus set, to a high degree, by the media's agenda, which articulates fluid moral and religious ideas that cannot be controlled by political power. That was the case with the youth rebellion of the 1960s, and that has been the case ever since. The way that the Danish company Arla Foods managed the Cartoon Crisis in 2005 and ever since shows that even the economic system must adapt to value politics and to religious policymaking. Today large firms are participating in symbol politics to a degree that no one could have imagined 20 years ago. For example, the board of Arla Foods is consciously working towards including religio-ethnic groups into their management.

If we are to understand secularisation as a retreat of religion from the centre of society, then we must immediately add to the list of retreating spheres even powerful systems such as politics and the economy. Though religion no longer finds itself at the centre of society, there is no reason to suppose that it will disappear from the public sphere. On the other hand, the major religious denominations, such as the Lutheran Church in Denmark, are expected to decline in relation to the total population (even though it lost only 3,000 members out of $4^{1} / 2$ million in 2005). At the same time it is likely that many smaller religious communities will come into being, while "faith in God is thinly smeared over everywhere," as the Norwegian sociologist of religion Ingvild Sælid Gilhus puts it. ${ }^{12}$
Religion is thus changing, but not actually declining. According to Luhmann, religion will survive for the simple reason that it deals with questions that can only be given a religious answer: What is the ultimate horizon for human life (which we cannot observe)? What is the purpose of life (which we cannot see)? And what is my or our specific task in life (which we must decide on based on pre-rational grounds)? Luhmann believes that religion is therefore necessary because it relates to recurring and emerging problems (Dauerprobleme), but its position tends to be weak because its forms of communication are by nature relatively vague. It is hard to speak with certainty of one's place in life, what we should spend our resources on, the purpose of suffering or its absurdity, how the individual's life fits into universal principles such as creation and salvation, samsara and nirvana, and so on.

The difficulty that religion faces is that faith or 'spiritual communication' has no medium that flows as well and effectively as money does in the economic system, or power in the political system. Religion therefore remains a rather uneasy system in the modern world. On the one hand, it is a limited player in the social system, yet on the other its universal themes stretch beyond the individual group and its members: life and death, joy and suffering, existence and annihilation.

Thus it is natural that religion is found in both solid and fluid forms-highly institutionalised or loosely flexible in its forms of communicationsince religious semantics (meanings and priorities) float around in society more or less independently of the religious commitment of the individuals. Religion functions as an underlying resource that orients the individual towards personal existence and social value.

\section{The Twofold Presence of Religion in the Public Sphere}

To understand the return of religion to the public sphere it is worth remembering that it is not only 
something one has (or does not have), but also something one does (or does not do). Religion is not merely about religious feelings, which emerge now and again and then evaporate, or about beliefs that one holds or gives up. Above all religion has to do with the orientation of life. This is also true of Christianity. Whether we look at the young Christianity of the early church or Christianity at the Reformation, three practical elements endure. They are:

- Issues of food and drink (what we take into the body)

- Issues of bodiliness, clothing and sexuality (use of the body and clothing as signals)

- The issue of images and other items in a physical space (that influence our imagination and fantasy)

It is not by chance that food and drink, body and clothing, and images have occupied the mind. Yet it is precisely Christianity that has helped to secularise their meaning-largely in the course of the $20^{\text {th }}$ century, with perhaps sexuality as the only exception. The privileging of the individual, which can be traced throughout the history of Western Christianity, was extended during $19^{\text {th }}$ century Romanticism to include the idea of the privileged beloved. Love must be of one's own free will, and yet it commits one to another. Despite attempts in the 1970s with free sexuality and open marriages, sexual life today is regarded predominantly as a privilege, at least after one has contracted oneself to a committed relationship.

Not only in Islam, but also in secularised Protestant forms of Christianity there are taboos, which are first discovered when they are violated. Danish legislation includes the taboo against killing (which goes back to the Jewish understanding of humanity being created in God's image, Gen 9:6, and whose historical context includes the killing of slaves). But Denmark also has a taboo in relation to the dead-see the Danish Penal Code Art. 139 on "the desecration of graves" and "unseemly treatment of corpses," punishable by up to 6 months' imprisonment. There also remains the moral taboo that one must not make fun of the suffering and death of others. So jokes about the Holocaust and torture are morally repugnant. When a group of Palestinian youths in Odense, Denmark publicly celebrated the $9 / 11$ attack on the World Trade Center, they provoked a deep animosity among virtually all native Danes. The holy zones of taboo are only discovered when they are violated.

\section{Conflicting Values and Preferences}

On the other hand imagery, food and drink, body and clothing have been desacralised in the Christian tradition. A predominantly Christian culture like that of Denmark has therefore found it hard to relate to Islam, since significant numbers of the Muslim population observe specific rules for food and drink, nakedness and clothing, as well as imagery. Islam defines itself through many of the same religious practices found in Christianity: devotion to God, prayer, and so on. However, it is characteristic that the public debate on Islam so often turns on pork and halal (what is taken into the body), on arranged marriages and the veil (what the body is used for), and now the cartoons of Muhammad (images in front of our eyes). Because religion is never totally invisible, it follows that it must appear in the public sphere too.

Religion is, of course, not just about eating regulations and so on; it is also present in the public sphere as a resource for practical decisionmaking. It is not just about 'ideas of God,' but also contains a set of values that serve to determine which preferences we have, and those we wish to live by. In modern society there are principles that all citizens are expected to share, as well as a whole series of choices. But between the general principles and the individual choices we have a large number of relatively shared, or overlapping, values and preferences that have their source in the great semantics of our comprehensive worldviews, and that we acquire through our upbringing and social life, for example through family and school.

When we look at the historical influence of Christianity in European and North American 
cultures, we find, for example, a strong preference for the individual. Such an orientation is far from universal, and is rare in African cultures, and in South and Eastern Asia. There are further preferences in relation to family and worklife, which draw on the resources from a Protestant ethics of vocation and work morale. Then there are preferences for the welfare state (in Europe, but apparently not in the US), and its concern for the public good that stretches beyond one's own family and ethnic groups. And so taxes are accepted by Northern Europeans to a degree that would be regarded as unreasonable in other cultures.

Such values or preferences continue to be negotiable of course; religious resources can both erode and return with renewed strength. It is also clear that non-religious equivalents exist as regards the individual, the family, work and the public good, such as in a post-Christian humanism. But it is difficult to ignore the fact that religions continue to be present in the public sphere as underlying models of orientation for what the good life consists of, and how in practice it can be achieved. Just as religion exists in both solid and fluid forms, so does Christianity appear in both church-related forms of Christianity and in a cultural Christianity, without the latter being necessarily less 'Christian' than the former. ${ }^{13}$

\section{Christianity's Contribution to Secularisation}

So far I have spoken relatively abstractly about 'religion' as a phenomenon, as though it were an object. But 'religion' is a designation for a host of actual religions that branch out into endless variants. It is now time to be more concrete and look at the particular historical conditions as to why, when the majority of Danes in September 2005 did not regard Jyllands-Posten's Muhammad cartoons as especially disgraceful, a great number of Muslims did. My point in the following is that Christianity itself has been instrumental in its own secularisation, inasmuch as eating habits, clothing and imagery have been seen as immaterial to keeping the faith. At the same time, Christianity has formed a special sensibility towards hypocrisy, which has a history of being exposed through satire and humour.

\section{The Jesus Tradition and the Distinction between the Inner and the Outer}

Let me here bring in a perspective from the Jesustradition. Some of Jesus' sayings have been particularly influential for the European-Christian mentality, especially those that focus on the distinction between the inner and the outer: "Do you not see that whatever goes into a person from outside cannot defile, since it enters, not the heart but the stomach, and goes out into the sewer?" (Thus he declared all foods clean.) And he said, "It is what comes out of a person that defiles." (Mk 7:18-23)

With this distinction between inner and outer not only is all food declared clean (though early Christianity continued to debate the subject, see Acts 11:1-18), but hypocrites and their double standards were put in their place, with a further reference to Isaiah: "This people honors me with their lips, but their hearts are far from me; in vain do they worship me, teaching human precepts as doctrines." (Mk 7:6-7)

The attack on religious hypocrisy led to a retreat from worshipping God so outwardly_praying in the streets and squares in order to be seen instead of in one's own heart of hearts (Mt 6: 1-3). But this also meant that evil could no longer be explained as always someone else's fault, with oneself as the perennial victim. Now evil came from within, and one should therefore examine oneself before judging others: "Why do you look at the speck of sawdust in your neighbor's eye and pay no attention to the plank in your own eye?" (Mt 7:3). Such Christian semantics have had major and lasting effects. We do not have to read many of the writings of Martin Luther before we run into sharp satire against the papacy and all the pomp and circumstance with which its bishops covered up the fact that it was hiding the gospel from the people. 


\section{Images and Hypocrisy}

Drawing again on this distinction between inner and outer it is also possible to understand why the majority of Danes (who hardly wish to mock Muslims' religious feelings) had not imagined that the Muhammad cartoons would be regarded as particularly disrespectful. For in a Christian culture, images are normally seen as peripheral to the central existential and religious message. There is no doubt that the effects of the Muhammad cartoons surprised the majority of Danes, including parliamentary politicians. By way of comparison we can look at the series of caricatures of Jesus' crucifixion published in Universitetsavisen, the official publication of the University of Copenhagen in the autumn of 2005 (and reprinted in spring 2006) that barely raised an eyebrow. Admittedly other works, such as Andres Serrano's Piss Christ (in which a crucifix with Jesus was soaked in the artist's own urine), have been regarded as disrespectful by certain Christian groups in the USA. But others have seen Piss Christ as a work of art calling for a religious reflection on the depth of divine incarnation into the very shit of this world.

It is doubtful whether Western Christianity has the sensibility to understand the offence caused by images. On the other hand, as we have seen, Christians have a strong aversion to hypocrisy and double-speak. When Arab governments, which themselves allow Judasim and Christianity to be violated in their own countries, asked the Danish government to apologise for picture published in a Danish newspaper over which the government had no influence, the vast majority of Danes, including a number of immigrants (who were themselves persecuted in Arab countries), experienced this as patent hypocrisy. And when imam Abu Laban of the Islamic Faith Community initially told Danish TV that the Community was against a boycott of Danish goods but a few days later argued for the opposite on a major Arab TV channel, this was taken in Denmark to be godless mendacity.

My point here is that the sense of hypocrisy is independent of whether individual Danes understand themselves as Christian believers or not.
There is a religious sensibility that has gone into the blood of the folk mentality. This is simply just one example of how a religion functions as a normsetter.

\section{The Pauline Tradition and the Christian Distinction Between Freedom and Benefit}

The criticism of the Jesus-tradition against flamboyant worship of God has not led to a general rejection of outward worship, but instead has made possible a new attitude to all visible and organised religion. Christianity was born as a freedom culture, building on the motto of the apostle Paul that "Everything is permissible for me' but not everything is beneficial" (1 Cor 6:12).

Thus Christian freedom should not result in inconsideration or callousness toward another. Ultimately, what is or is not beneficial always has to do with the weaker neighbor. Let the one weak in faith eat vegetables (and not meat from the Roman temples), says Paul, as long as s/he does so in Christ (Rom 10). Let you heathens have your images, they are not worth anything anyway, he says to the Athenians:

Athenians! I see that in every way you are very religious... But the God who made the world and everything in it is the Lord of heaven and earth and does not live in temples built by hands... For in him we live and move and have our being. As some of your own poets have said, 'We are his offspring.' Therefore since we are God's offspring, we should not think that the divine being is like gold or silver or stone - an image made by mortal design and skill. (Acts 17:22-29)

Again we meet the same line of thinking. Paul obviously regards images of God as an expression of religious misunderstanding. But the tone is conciliatory, since he regards those who worship images of God as confused. What they need is clear preaching and religious instruction, not violent suppression. 


\section{John of Damascus on the Limits of Image Worship}

But images do have an effect. That is why in Christianity too there was a dispute over images in the $8^{\text {th }}$ and $9^{\text {th }}$ centuries; moreover, this occurred under the influence of Islamic thought. ${ }^{14}$ The so-called iconoclasts referred to the prohibition against images in the Old Testament, while the iconolaters (image-worshippers) maintained that although the eternal God could not himself be depicted, nevertheless one is allowed to make pictures of Jesus Christ, in whom God has entered in the world of the flesh and the image. Does not Paul tell the Colossians that Christ is "the invisible God's (visible) image" (Col 1:15)?

The defining theologian was here John of Damascus (680-749); it was he who formulated the following theological ground rules that became normative in both the Eastern and the Western church:

- God's nature (ousía) cannot be depicted, but God's energies (energeiai) and the grace (charis), through which He approaches humanity's imagination can.

- Images can therefore not be worshipped; only God can be worshipped (latreia).

- Images may however serve as paths to God, and in that sense may be embraced with veneration (time) and worship (proskynesis)

- Hence the image is only a depiction (ektypos) of the reality of the divine image (archetypos) which alone is worthy of worship.

- Since God has become human in Jesus Christ, depictions of him are allowed, well-knowing that it is through his human manifestation that his divine nature is worshipped.

Ultimately it is belief in the incarnation that makes the use of imagery legitimate for the church: "In honouring the image of the precious and lifegiving cross, we are honouring not the wood (God forbid!), but we are honouring the image as a symbol of Christ ... Everything is therefore directed towards God, whom we worship, in that we transfer worship from the image to him" (De fide Ortodoxa, IV, 11).
This solution was elevated to orthodox doctrine at the Council of Nicea in 787, and despite recurrent disputes on the subject in the $9^{\text {th }}$ century it remains normative theology. In the words of the great medieval theologian Thomas Aquinas, images rank far below humanity in status, for it is humanity who has fabricated the images and not the other way round. Nonetheless images have a legitimate function in the religious life, in that "the image's honour is passed on to the prototype, that is, God himself" (Summa Theologiae III q. 25 a 3). Evidently, this is a continuation of John of Damascus' argument.

The laying down of these principles did not prevent a steady criticism of the excessively luxurious imagery throughout the Middle Ages; at the same time it was defended for its educational value. For what the scholar can read in the Bible, the illiterate layperson must acquire through perception. This view, which can be traced back to Pope Gregory the Great (c. 540-604), has led to Christianity's wealth of imagery in medieval icons and frescos, and the richly illustrated Bibles known as Biblia pauporum or Bibles for the poor-not because they were cheap but because they could be read by illiterates.

\section{Luther and Calvin on Imagery}

Nevertheless the dispute over images dragged on into the Reformation, at which point iconoclasts like Andreas Karlstadt and his supporters smashed images in the churches of Wittenberg in 1520-21, while Luther was in exile in Wartburg castle. The desire for white, unpainted churches also became the norm in the Calvinist churches, which took the prohibition against imagery in the Ten Commandments quite literally.

By contrast, Luther followed John of Damascus' theological arguments and Gregory the Great's educational argument. The difference can be seen in the amount of ink and energy that John Calvin (1509-1564) expends on his commentary to the Ten Commandments, telling his readers that because God is invisible and without form, he cannot and must not be worshipped through any 
human-made image, not even for educational purposes (Institutio I,11, 1559).

Luther on the other hand chose not to treat the second commandment on graven images in the Small Catechism and the Large Catechism from 1529. According to him the Ten Commandments are of their time, and though still apposite as a formulation of natural law of conscience, to which all human beings can subscribe, he points out in a Lenten sermon in 1521 (immediately after his return to Wittenberg) that the Old Testament contains numerous examples of Noah, Abraham and Jacob building altars to the honour of God (Gen 8:20; 12:7; 33:20). Even Moses used a copper snake as an image of God's guidance (Num 21:9). As Luther says in the third Invocavit Sermon in 1522, "Here we must admit that we can have images and may fabricate images, but we must not worship them, and if they are worshipped, they must be removed and destroyed." 15 We do not serve God through images, but there is no reason to destroy them, for in reality they are harmless.

The deeper reason for Luther's relaxed attitude to images is that a prohibition will make no difference anyway. For it is above all the mental pictures we conjure up of God that can throw us off track (in the spirit of the law), or build us up (in the spirit of the gospel). False allegiance to the law involves us removing the outer images yet filling ourselves up inside with idols, he says in a later work against the Anabaptists from 1525. ${ }^{16}$ Luther's position may be summed up in three main points that fuse together the distinction between the inner and the outer that we found in the Jesus-tradition, and the freedom-and-benefit view from the Pauline tradition:

- "Everything is free" (p. 91); hence the question of imagery is a secondary matter.

- "One is to trust alone in Christ" (p. 91); accordingly each believer is responsible for destroying the false images with the Word of God, not through the law but through the gospel.

- "For the sake of remembrance and better understading" (p. 99), it can be beneficial to make use of images, especially images of Christ.
Thus by all accounts the Lutheran Reformation has played a decisive role in creating a relaxed attitude toward religious images, and thence to a secular view of human art products. At the same time God, according to Luther, is alive and present in the world of the senses: "Our home, farm, field and garden and everything are full of the Bible, by which God through his wonderful deeds not only preaches to us but also taps on our eyes, touches our senses, and in secret illuminates our hearts" (Sermon of $25^{\text {th }}$ May 1544). ${ }^{17}$

\section{The Twofold Inheritance of Luther's Doctrine of the Two Kingdoms}

The Lutheran Reformation was born as an internal church reform movement with a clear theological profile. But how would this religious vision translate into an idea of social community? Historically we know that in the beginning Luther and his associates had no vision for society. But on December $10^{\text {th }} 1520$, when he burned the canon law together with the papal bull of excommunication, he was not only calling into question the pope's religious authority, he was also performing a political act —in the middle of the public sphere. Religion became politics.

The task ahead was to find out what type of society should be built up, now that canon law had ceased to rule. Luther's response was his famous doctrine of the two kingdoms, as revealed in particular in the work, Temporal Authority: To What Extent it Should be Obeyed, from $1523 .{ }^{18}$ It is this doctrine of Luther's that has further contributed to the self-secularisation of Christianity, without ever leading to a total separation of religion and politics, however.

\section{The Kingdom of God and the Kingdom of the Devil}

In this work on secular authority, Luther builds on the view of Augustine that the kingdom of God in this world is confronting the kingdom of the devil in single combat. Correspondingly, Luther divides people into two groups: "the first belonging to the kingdom of God, the second belonging to 
the kingdom of the world" (p. 88). Luther was definitely not an optimist on behalf of humanity or Christianity. Even though he lived in a society in which everybody (with the exception of a few Jews) was baptised and raised in the Christian faith, he was convinced that very few were actually Christians: "the world and the masses are and always will be un-Christian, even if they are all baptized and Christian in name. Christians are few and far between (as the saying is)" (p. 91). Society therefore cannot be built on the goodness of humankind, which is a rare phenomenon, but solely on public order, which keeps wickedness down. It is therefore an important point in the doctrine of the two kingdoms that, in the final count, it is God who rules the world, both "by the word" (by persuasion) and "by the sword" (by force). The devil himself is merely a creature, not a divine power alongside God.

\section{The Purpose of the State's Power}

When the gospel is publicly preached, faith is offered to all citizens of society, but it is always voluntary. This is crucial to Luther, and it explains why he opposed church discipline. "No one shall or can command the soul, unless he is able to show it the way to heaven; but this no man $[s i c]$ can do, only God alone” (p. 106). Luther therefore strongly resists the attempt by the state to force anyone into faith by legislation or some other way: "Therefore, where the temporal authority presumes to prescribe laws for the soul, it encroaches upon God's government and only misleads souls and destroys them" (p. 105). This awareness of the limits of the state paved the way for subsequent constitutional notions of freedom of religion.

But the crucial point is that God also protects public order through the legal system and political power. The authorities must of necessity act with force. Because the world is with the wicked"among thousands there is scarcely a single true Christian"-we have the sword of the authorities so that the wicked "are obliged to keep still and to maintain an outward peace" (p. 91). Here we find the view of political power as the source of a society governed by law, but also a power that ultimately has the means to uphold law and order through the penal system if the law is violated. This power does not exist for the sake of the authorities, but for the weak in society who would otherwise be overwhelmed by the wicked.

\section{The Christian and the Political Realm}

The question for Luther was then whether evangelical Christians could participate in the authorities' exercise of power without damaging their souls. His answer was a resounding 'yes.' Not only is it possible for a Christian to participate, indeed it is a duty to be a judge, a soldier, a hangman. For the authorities are installed by God for the benefit of the weak in society. Here, then, is the structure of Luther's doctrine of the two kingdoms:

- There is only one God, who rules the world (the monotheist premise)

- God rules the world with his right hand and his left hand

- With God's right hand God rules the life of the church through the preaching of the gospel, which can only be received voluntarily, without church discipline or force from the authorities

- With God's left hand God rules society as a whole through authorities, which must exert force to bring the wicked to keep the law (preventative) and to uphold the rule of law for the benefit of the weak (protective).

From this summary one could regard Lutheranism as a forerunner of the liberalist state, which combines the powers of the state with a sense of what lies outside its domain: the citizens' faith and doubt, their hope and desperation, their love and lack of love. And it is true that Luther abolished the earlier medieval view that the worldly authorities are subordinated to the order of the church.

\section{The Interdependence of the Two Kingdoms}

However, on closer scrutiny we discover that the political programme that Luther and his associates worked out in the course of the 1520s also included powerful interplay between the spiritual and the 
secular regiments. It was a ruler's duty, for instance, to ensure that the gospel was indeed preached in freedom to the citizens, so that there would be the possibility that faith could grow among them. As a modern counterpart, we might note that both pastors and imams are attached to the Danish prison service, and the desire for spiritual care for the inmates will hardly decrease over the coming years.

In the second place, Lutheranism also had a complete cultural programme for reorganising society. This was because society was not seen as a godless territory but as an area within which God's 'natural law' ruled. Whereas marriage in a Catholic context was regarded as a church sacrament, in the Protestant church it was now seen as a civic arrangement pleasing to God; marriage is not about eternal bliss but about happiness and well-being. Whereas education belonged previously under the Church, there were now serious moves towards a public education system, since education was good for both society and for the individual. For example, the Reformation of the Danish church in 1536 was decisive for the renovation in 1537 of the University of Copenhagen, which had fallen into disrepair. Also the legal system was similarly reformed, with the courts being moved from Church to state jurisdiction, whereas large areas of canon law continued as they were. The idea was that equality should prevail while people remained free to follow particular traditions. ${ }^{19}$ It was similar in the case of the citizens' health and of relief for the poor.

In organisational terms all this must be seen as a move towards secularisation; but as regards content everything points to religious themes acquiring a more prominent place than before. We only need to look at the list of contents in the Danish Church Ordinance of $1537 / 39$ to observe how the visiting of the sick and the poor, instruction of midwives and women in confinement, school attendance, poor relief and and hospitals are far more conspicuous in the Church's - and thus society's - understanding of its tasks. ${ }^{20}$ In brief: along with the division of the spiritual and the temporal regiments came an increasingly reciprocal permeation of the religious and political sphere. The civic regulations were introduced not just preventatively and protectively to safeguard society from evil, but also positively and procreatively to take care of the welfare of its citizens in a broader sense. As we read in the Confessio Augustana article 21, the regulations of society and the family, are to be upheld as "God's good regulations... so that love can be exercised in them." 21 Hence, Christian love is the measure for what is right and proper, including in the secular realm.

\section{Modern Consequences}

Accordingly, the political programme of Lutheranism not only led to a secular state governed by law and order but also to the formation of the modern welfare state, in which citizens dare to trust that the state wishes them well; while the state knows that politically it cannot make its citizens either happy or blessed. In this connection we must ask why precisely Denmark became the first country to introduce compulsory school attendance (in 1814), and the second country, after Germany, to introduce the old age pension (1891), for both men and women. The political scientist Tim Knudsen and the historian Uffe Østergaard have attempted to trace the roots of the comprehensive welfare state back to the Lutheran understanding that grace (in the spiritual kingdom) is given free of charge. In similar fashion, the Scandinavian countries have created the so-called 'universal welfare state' (within the temporal kingdom), where services are given to all citizens for free, whether or not they deserve them, and irrespective of any private pensions. ${ }^{22}$ This idea of the universal welfare state is not itself universal; its emergence depends on specific religio-cultural conditions.

The Lutheran doctrine of the two kingdoms thus has had a twofold historical effect. On the one hand it has laid the foundation for a liberalist separation of religion and politics, each of which has its sphere of influence. On the other hand the spiritual kingdom has provided inspiration for civic regulations, resulting in a conservative, later on a social-democratic, welfare state. The distinction is made between religion and politics, but the two domains have never been separated; nor was such separation ever intended. 


\section{The Politics of Separation versus the Politics of Recognition}

In contrast to Luther's time we no longer live in a guardian state, where care of the citizens' well-being is controlled by an autocratic political system. Most of us in the West now live in a centreless society without a ruling midpoint, where political values are constantly negotiable, and the sources for political preferences come from many places. We also live with a global consciousness, in which Christianity's cultural resources are no longer assumed, and ideas and influences flow across national borders and cultures. The question for us is what does this mean for religious politics today? I see two basic possibilities.

We can either work towards a secularist solution, according to which the political sphere requires a limitation of the religious life in principle to the private sphere-leaving the public sphere as free of religion as humanly possible. Or we can work towards a politics of recognition, which acknowledges the actual existence of religious practices and ideas in the public sphere, and therefore recognises that the borders between the political system and the religious life are constantly negotiable, depending on the character of the religious cultures in any given society at any given time.

\section{A Secularist Solution}

The former is the French model for a joint-state secularism (lä̈cité), which forbids religious symbols (from cross to veil) in the public sphere, including the teaching of religious studies in the public schools. This model is echoed in the First Amendment to the US Constitution. The politics of recognition model has been the common European model, in which society makes legal compacts with specific faith communities (e.g. in Italy, Spain or Austria) or undertakes other legal regulations of its relationship to religious groups as recognised and approved faith communities. ${ }^{23}$

\section{A Politics of Recognition}

Denmark is an example of the second model. When Article 4 of the Danish Constitution was passed in 1849, it said: "The Evangelical Lutheran Church shall be the Established Church of Denmark, and, as such, it shall be supported by the State." The thinking was that the new democracy should recognise the prior existence of a huge majority church, and thus the Constitution promised a church order in Article 66: "The constitution of the Established Church shall be laid down by Statute." This so-called 'promissory clause' has never been made good. Similarly, the Constitution promises in Article 69: "Rules for religious bodies dissenting from the Established Church shall be laid down by Statute;" but neither has this clause been made good in the form of an overall law for religious communities. Over time 104 such communities of widely varying type and size have been 'recognised' and 'approved.' Despite all differences and obscurities the State of Denmark has thus recognised certain religious cultures as reciprocal collaborators. $^{24}$

In this respect the Constitution contains specific clauses relating to freedom of religion and freedom of speech:

Article 67: "The citizens shall be entitled to form congregations for the worship of God in a manner consistent with their convictions, provided that nothing at variance with good morals or public order shall be taught or done."

Article 77: "Any person shall be entitled to publish his thoughts in printing, in writing, and in speech, provided that he may be held answerable in a court of justice. Censorship and other preventive measures shall never again be introduced."

These are clear principles that establish individual religious choice. No one can censor either religions themselves, or statements for or against religions. But my collegue, Henning Koch, professor of law, has pointed out that the use of these two freedoms comes with a legal responsibility for maintaining public law and order. 


\section{The Role of the Legal System in the Cartoon Crisis}

When we look back at the effect of the Muhammad cartoons on Denmark's reputation, we can wonder at the absence of the legal system in the debate. For the Danish Penal Code Section 140 states: "Those who publicly mock or insult the doctrines or worship of any religious community that is legal in this country, shall be punished by a fine or imprisonment for up to four months."

This so-called 'blasphemy law' protects neither God nor Jesus nor prophets from insults, but it protects religious groups in general. ${ }^{25}$ In a similar fashion Section 266b penalises statements that "...threaten, insult or degrade a group of persons on account of their race, colour, national or ethnic origin, belief or sexual orientation," with up to 2 years' imprisonment. Individuals are also protected against violation of honour (Section 267), against spying and photographing in a "not freely accessible place" (Section 264a), against threats on their "life, health or well-being" (Section 266), or appeals to "acts of violence and vandalism" (Section 266a), and so on. ${ }^{26}$

How then to balance the right to practise religion without public mockery with the right to freedom of speech? It is clear that legally neither freedom of religion nor freedom of speech are unlimited. But freedom of speech ensures that religions can be criticised both for their claims to truth and for their socio-ethical consequences. Criticism of religions is allowed (and in my opinion is even beneficial), just as criticism is allowed of the ethics of a religion for being paternalistic, oppressive to women and so on. But such criticism is not allowed that summarily insults the creed of a religious group in order to deride it.

\section{Applicability of the Blasphemy Law}

The question now is whether the blasphemy law reasonably can be applied against Jyllands-Posten. The problem, from a legal point of view, can- not be the drawings of Muhammad in themselves, but rather the text that accompanied the cartoons. As mentioned above, the paper's cultural editor wrote that Muslims must also learn that in a secular democracy with freedom of speech one must be ready to a live with "scorn, mockery and ridicule." It is in this spirit that the Muhammad-cartoons were published the following day. During the heated discussions in Denmark in February 2006, in the company of several law professors, I therefore publicly supported the request of Muslim groups that a Danish court should test the claim that the Muhammad cartoons were published precisely in order to insult and ridicule Muslims in Denmark (and elsewhere). This request was then considered by the public prosecutor.

On March 15, 2006, he finally rejected the case, based on (probably legally reasonable) obstacles for winning this particular case. He did so on several grounds, of which the following were the more important: the prohibition against images of Muhammad is in fact not universal within Islam; a number of the cartoons must be designated as neutral; and even the cartoon which shows a bomb in Muhammad's turban can be interpreted in several ways, including as a socio-ethical criticism of the use that is made of Muhammad within areas of radicalised Islam. At the same time, however, the public prosecutor upheld in his conclusion that Sections 140 and 266b of the Penal Code do eventually set limits to freedom of speech as regards religious and ethical subjects.

The public prosecutor's additional argument for not proceeding with the case was that the precedents are few and far between; the last conviction in Denmark for blasphemy was as far back as 1938. Other reasons for not bringing charges were also provided. Henning Koch has pointed out that since the prohibition against depicting Muhammad does not exist in the Qur'an but only in the Hadiths, it hardly can be regarded as an insult of central 'doctrines.' Against this, one could argue that the case is not just about what the Qur'an says (which would correspond to a Protestant scripture principle), but rather about what is important for Islam as it is lived in Denmark. Section 140 deals 
precisely with protecting "the doctrines or worship of any religious community that is legal in this country." Add to this the fact that the pictures were not neutral depictions of Muhammad but caricatures that identified the prophet with Islamic terrorism and were thus calculated to mock and deride certain groups of believers among the Danish people, I still cannot understand why such a case has not been brought.

\section{A Political Policy of Religious Blindness}

The argument for doing exactly that is that a case would be held within the framework of official Denmark. And such an answer from official Denmark was not heard until the statement of the Conservative Minister for Foreign Affairs, Per Stig Møller. Prime Minister Anders Fogh Rasmussen rightly pointed out that according to the Constitution he cannot as Prime Minister censor the press, and that therefore he cannot apologise for editorial choices for which he has no responsibility. On the other hand as a statesman he could have deplored the publication on behalf of official Denmark, and not just as a private person. He could have listened to the many experienced diplomats at the Ministry of Foreign Affairs who are used to moving in cultures other than the EuroAmerican one. He could have expressed a willingness to protect a minority from political rhetoric aimed at immigrants, one that has been allowed to grow even among parliamentary politicians in a party supporting the present government. In other words, the Prime Minister could have responded within the framework of the politics of recognition instead of pursuing a policy that pretends that religious minorities are of no concern of the state. It is this policy of blindness to religion that has been perceived as arrogant and disrespectful of other nations, obviously against the Prime Minister's own intentions.

In the same way we can ask whether the misinformation that a delegation from the Islamic Faith
Community in Copenhagen has spread in Muslim circles in Egypt and elsewhere is not covered by the Section 129b of the Penal Code, which states: "Whoever damages the interests of the country by consciously and untruthfully publicly ascribing to the government or any other public authority an act which it has not undertaken shall be liable to a fine or imprisonment up to 2 years." It is perfectly possible that this law, which deals solely with misinformation regarding the government and public authorities, cannot be applied to the misinformation on behalf of a newspaper, Jyllands-Posten. But if that is the case, we might ask whether Parliament should not legislate against such actions that threaten public law and order. Admittedly it would only be 'symbolic legislation,' but even that can be beneficial if the overall aim of the law is to maintain law and order.

\section{Protecting the Public Debate}

The effects of the Mohammed-cartoons can only be described as quite all out of proportion, and many parties contributed to the escalation of the conflict. What can be learned from it all is that everything that belongs within the life of society, including religions and cultures, must be part of the political dialogue. But dialogue in itself is not enough; the legal system is also required to set limits on hate speech from whatever side. There is no need of a law for the benefit of Muslims-or against them for that matter. What is needed are laws that demonstrate the politics of recognition in relation to all the practising religions in Denmark, a politics of recognition that, of course, at the same time must make demands on those groups who ask for society's respect.

Legally we need not a lex islamica, but a law on right and reason. Morally we do not call for agreement on our various views of life or our preferences, but merely for a proper tone in which to conduct the public debate. 


\section{Endnotes}

1. This article is an expansion of a public lecture given for the major conference "Gudebilleder" at Copenhagen University, February 20, 2006. The conference was called for by the President of Copenhagen University in the midst of political turmoils. It was organized by the Copenhagen University Research Project on "Religion in the $21^{\text {st }}$ Century" and extensively covered by all Danish media. The subsequent book, Gudebilleder: Yringsfrihed og religion i en globaliseret verden [Pictures of Gud: Freedom of Speech and Religion in a Globalized World] (Copenhagen: Tiderne Skifter, 2006) was edited by Lisbet Christoffersen. I thank Edward Broadbridge for translating the first draft, and doctoral student Jennifer Veninga (Graduate Theological Union) for helpful advice.

2. All drawings can be seen on www.brusselsjournal.com/node/698.

3. This quotation from www.da.wikipedia.org/wiki/Muhammedtegningerne, accessed July 23, 2008, which also offers access to other source texts quoted below. At least a half dozen books have been published in Denmark on the crisis. I recommend in particular Per Bech Thomsen, Muhammedkrisen — hvad skete der, hvad har vi lart [The Mohammed Cartoon Crises-what happened, and what have we learnt] (Copenhagen: People's Press, 2006), which aims to even-handed and is based on extensive interviews with ten main actors during the crisis 2005

4. "22 tidligere ambassadører siger fra", Politiken, December 20,

5. Analyzed and put in historical perspective in Niels Henrik Gregersen, "Religion in der Öffentlichkeit. Die Zwei-Regimente-Lehre zwischen Privatisierung und Governmentalisierung," Forum historiae iuris (August 2008 Humboldt University), at www.rewi.hu-berlin.de/FHI.

6. See Peter L. Berger, The Sacred Canopy: Elements of a Sociological Theory of Religion (New York: Anchor Books, 1967). Berger was one of the first to discover that even though religion is no longer a matter of course (as it was in pre-modern society), the religious traditions continue, even with renewed vitality, see A Rumor of Angels: Society and the Rediscovery of the Supernatural (New York: Anchor Books, 1970). A brief diagnostical overview can be found in "The Desecularization of the World: A Global Overview" in Peter L. Berger: The Desecularization of the World: Resurgent Religion and World Politics (Grand Rapids: Eerdmans, 1999), 1-18.

7. Jürgen Habermas, Theorie des kommunikativen Handelns I-II (Frankfurt a.M.: Suhrkamp, 1984), vol. I, 225-298.

8. I have presented a crictism of the theory of secularisation from Weber to Habermas in Teologi og kultur. Protestantisme mellem isolation og assimilation i det 19. og 20. århundrede (Aarhus: Aarhus University Press, $1988 / 2001^{2}$ ), 136-162. The most convincing alternative I know of is the historically sensitive theory of David Martin, see David Martin, "What I Really Said about Secularisation," Dialog 46:2 (summer 2007), 139-152.

9. Jürgen Habermas, "Religion in der Öffentlichkeit. Kognitive Voraussetzungen für den 'öffentlichen Vernunftgebrauch' religiöser und säkularer Bürger" [2005], in Zwischen Naturalismus und Religion. Philosophische Aufsätze (Frankfurt am Main: Suhrkamp, 2005), 119-154 (quotation at 121).

10. "Religion in der Öffentlichkeit", 137.

11. See Niklas Luhmann, Funktion der Religion (Frankfurt am Main: Suhrkamp, 1977), plus a whole series of later treatments of religious semantics, some of which were posthumously published in Die Religion in der Gesellschaft (Frankfurt am Main: Suhrkamp, 2000). See my analysis, "Religions umulige nødvendighed. Niklas Luhmanns rotteblik på religionen," in N. Luhmann et al., Autopoiesis. En introduktion til Niklas Luhmanns verden af systemer (København: Politisk Revy, 1992), 97-127. I should add that only sporadically does Luhmann himself include resonance ("interpenetration") between the different-in-kind systems.
12. Ingvild Sælid Gilhus, "Gudstro smurt tyndt udover," Gudstro i Denmark, Morten Thomsen Højgaard and Hans Raun Iversen eds. (Frederiksberg: ANIS, 2005), 83-102.

13. Cf the debate raised in Denmark by Jørgen I. Jensen's major work, Den fjerne kirke. Mellem kultur og religiøsitet (København: Samleren, 1995), followed by Niels Henrik Gregersen, Den dobbelte kristendom (Herning: Poul Christensens Forlag, 1996), and Jørn Henrik Olsen ed., Kulturkristendom og kirke (Valby: Unitas, 1999).

14. Hans Georg Thümmel, "Bilder V/1", Theologische Realenzyklopädie (TRE), Band 6, 532-540, qoutation at 535.

15. Martin Luther, "Eight Sermons at Wittenberg, 1522," in Luther's Works vol. 51, John W. Doberstein ed. and trans. (Philadelphia: Fortress Press, 1959), 82.

16. Martin Luther, "Against the Heavenly Prophets in the Matter of Images and Sacraments" [1525], in Luther's Works vol. 40, Conrad Bergendoff ed. (Philadelphia: Fortress Press, 1958), 99-100. The following references are to this text.

17. Weimarer Ausgabe vol. 49, 434 (not included in Luther's Works).

18. Martin Luther, "Temporal Authority: To What Extent it Should be Obeyed" [1523], in Luther's Works vol. 45, Walther I. Brandt ed. (Philadelphia: Fortress Press, 1962), 75-131. The following references are to this text.

19. On the entire development see John Witte, Jr., Law and Protestantism: The Legal Teachings of the Lutheran Reformation (Cambridge University Press 2002). Witte examines in detail the comprehensive programmes for reorganising society that followed on from the Reformation.

20. Kirkeordinansen 1537/39. Tekstudgave med indledning and noter ved Martin Schwarz Lausten (København: Akademisk Forlag, 1989).

21. The Augsburg Confession XVI, in The Book of Concord: The Confessions of the Evangelical Lutheran Church, eds. Robert Kolb and Timothy J. Wengert (Fortress Press: Minneapolis, 2000), 48-51. Thus, the doctrine of the two regiments needs to be seen in the context of Luther's view of the three orders: ecclesia, oeconomia, and politia. A fine analysis in Risto Saarinen, "Ethics in Luther's Theology: The Three Orders," in Jill Kraye and Risto Saarinen eds., Moral Philosophy at the Threshold of Modernity (Dordrecht: Springer, 2005), 195-215.

22. Tim Knudsen, "Tilblivelsen af den universalistiske velfærdsstat," in Tim Knudsen ed., Den nordiske protestantisme og velfardstaten (Aarhus: Aarhus University Press, 2000), 20-64, and Uffe Østergaard, "Lutheranismen og den universelle velfærdsstat," in Jens Holger Schjøring and Jens Thorkild Bak eds., Velfordsstat og kirke (Frederiksberg: ANIS, 2005), 147183; Tim Knudsen's thesis is followed in The Nordic Model of Welfare: $A$ Historical Reappraisal, Niels Finn Christiansen et al. eds. (University of Copenhagen: Museum Tusculanum Press, 2006), 10.

23. See the overview in Lisbet Christoffersen, "Konvergerende religionsret-Danmark og Europa", in Religion, skole og kulturel integration $i$ Denmark og Sverige, Peter B. Andersen et al. eds. (University of Copenhagen: Museum Tusculanum, 2006), 21-60.

24. See the overview in Hans Raun Iversen, "Religionsfrihed og religionslighed i Danmark," in For Folkekirkens skyld - at forny for at bevare, Frederiksberg: Unitas 2004, 33-59. Iversen here points to a number of inconsistencies and inequalities in Danish legislation on religion, e.g, between the 12 'recognised' faith communities (before 1969) and the 92 'approved' faith communities (since 1969).

25. See the analysis by Henning Koch, "Ytringsfrihed og tro," in Gudebilleder (note 1), 72-88.

26. The link between blasphemy law and the sections against hate speech has been pointed out by Lisbet Christoffersen in "Blasfemisk blindhed," Biskop for herren - and så mange andre. Festskrift til Kjeld Holms 60-årsdag, Anna Ehlers et al, eds. Frederiksberg: ANIS 2005, 189-211. 